\title{
Effect of water removal on introduced caddisflies from a tropical mountain stream
}

\author{
M.D. McIntosh ${ }^{1 *}$, M.E. Benbow ${ }^{1}$, A.J. Burky² \\ ${ }^{1}$ Department of Entomology, Michigan State University, East Lansing, MI 48824-1115, USA \\ 2 Department of Biology, University of Dayton, Dayton, OH 45469-2320, USA
}

\begin{abstract}
Tropical island streams worldwide are being threatened by existing or proposed dams and diversions. Numerous streams of the Hawaiian Islands have diversions that remove freshwater for human use; however, little research has addressed diversion effects on aquatic insect communities in tropical streams. We studied the effect of water removal by a stream diversion on density and biomass of two introduced Trichoptera, Cheumatopsyche analis (Banks) (Hydropsychidae) and Hydroptila potosina (Buenoa-Soria) (Hydroptilidae), in Iao Stream, Maui, Hawaii, from April-August 2000. Both species seem to have multivoltine life cycles. Pooled Trichoptera (both species) biomass was significantly greater above the diversion $\left(178.3 \mathrm{mg} \cdot \mathrm{m}^{-2} \mathrm{and} 112.9 \mathrm{mg} \cdot \mathrm{m}^{-2}\right.$ for upstream and downstream, respectively). For each individual species the mean total instar biomass was significantly reduced below the diversion (38\% and $54 \%$ reduction for $C$. analis and $H$. potosina, respectively). Both species had greater densities above the diversion; however, individual larval mass of $H$. potosina instars, but not $C$. analis instars, was significantly lower below the diversion. Our results suggest that reduced habitat quality, due to lowered stream flow, limits density of both species below the diversion, whereas lowered food quantity and quality may differentially affect $H$. potosina biomass through reduced body sizes. These data suggest that water removal not only reduces habitat quality, but significantly lowers the community biomass of these introduced Trichoptera species, affecting the trophic energetics of stream reaches downstream of a diversion in Hawaii. Similar changes to macroinvertebrate communities would be expected below dams and diversions of streams in other tropical regions.
\end{abstract}

Keywords : diversion, reduced flow, stream, Trichoptera, macroinvertebrates, tropical.

\section{Introduction}

Tropical island streams worldwide are being threatened by existing or proposed dams and diversions, mainly due to population growth and development (Benstead et al. 1999, Pringle et al. 2000). Although subsequent reduction in stream flow can disrupt the life cycle of important migratory fauna found within these tropical streams, little research has been conducted to document the effects of water removal on these organisms and the entire stream ecosystem (Benstead et al. 1999, March et al. 2002). Diversion removal of normal stream flow can result in alterations of stream habitat downstream, thus, affecting the benthic community. Alteration of stream flow may limit habitat availability, shift species interactions, and eliminate

\footnotetext{
*Corresponding author : E-mail : mcinto57@msu.edu
}

both native and introduced aquatic species; therefore, altering the entire food web (Poff et al. 1997). Most studies have addressed top-down affects of macroconsumers (e.g., fish, shrimp and snails) (Way et al. 1998, Benstead et al. 1999, March et al. 2002); however, to completely understand the effects of water removal, studies also need to investigate possible bottom-up effects on the aquatic community.

In the Hawaiian Islands approximately $25 \%$ of the 376 listed perennial streams are diverted for anthropogenic uses (e.g., agriculture, tourism) (Hawaii Cooperative Park Service Unit 1990). On the islands of Oahu and Hawaii, one-third of the streams are diverted; whereas on Maui one-half of the 90 perennial streams are diverted. Because of the high percentage of diverted perennial streams, in addition to increasing urban development, research effort into understanding the effects of diversions is becoming increasingly important, yet few studies to date have been published on this issue. By understanding the effects of water reduction on lower trophic levels (e.g., aquatic insect communities), 
it might be possible to estimate changes associated with other aspects of the ecosystem (e.g., fish populations). Thus, a need exists in tropical stream research to understand the effect of water removal on all macroinvertebrates, especially those fundamental to higher trophic levels (from the bottom up). However, in order to understand the impacts of water removal, more information is needed on the general ecology, life histories and energetic interactions of aquatic insect communities found in tropical streams. Ultimately, a more comprehensive understanding of native and introduced aquatic insect community dynamics compared to a single species perspective would be beneficial to future stream management decisions in Hawaii, and in other tropical regions of the world.

Other than taxonomic lists (Zimmerman 2001), little published information exists on aquatic insect ecology and biology in Hawaiian streams (Kondratieff et al. 1997, Benbow et al. 1997, Benbow 1999), and even less information can be found on the effect of water removal on these insect communities. A study by McIntosh et al. (2002) found Diptera (native and introduced) to be the dominant taxa $(64 \%)$ in riffle habitats; however, the second and third most abundant taxa were two introduced Trichoptera, Hydroptila potosina (Bueno-Soria) (Hydroptilidae) $(15 \%)$ and Cheumatopsyche analis (Banks) (Hydropsychidae) (8\%). A similar study by Kido (1993) found $C$. analis to be the dominant taxa (68\%), succeeded by Diptera (19\%) and $H$. potosina $(9 \%)$. Life history studies have been completed by Kondratieff et al. (1997), that determined the life cycle of $C$. analis on the island of Molokai, and Benbow et al. (1997, 2003), determined the life cycle and habitat preference of a single midge species, Telmatogeton torrenticola (Terry), on the island of Maui. Englund \& Polhemus (2001) have studied the affect of introduced fish on indigenous and endemic aquatic insect taxa. Brasher (1996, 1997a,b) and Way et al. (1998) have studied diversion effects on the native amphidromous fish, shrimp and snails of Hawaiian streams. However, relatively little published research has focused on the effects of diversions on native and introduced aquatic insect communities, beyond a recent study by McIntosh et al. (2002) that found invertebrate communities were negatively impacted by diversions. Kido (1996) and Wolff (2000) found negative diversion impacts on invertebrate and algae communities in Hawaiian streams, but all of these studies mainly addressed density differences. To our knowledge no published studies have documented differences in energetics (e.g., insect biomass and body size) due to water removal by diversion.
The roles of $C$. analis and $H$. potosina have been addressed in trophic food web studies of Hawaiian streams, specifically as a dietary component of native fish (Kido 1993, 1997a, 1997b, Way \& Burky 1991). Gut analyses of a native fish, Awaous guamensis (Valenciennes), found reduced numbers of native insects with increased dietary reliance on introduced taxa, specifically C. analis and H. potosina (Kido 1993). Simplified food webs for two native fish, Awaous guamensis and Sicyopterus stimpsoni (Gill), included both of these Trichoptera as links between primary producers (algae) and secondary consumers (fish) (Kido 1997a). The increasing role of $C$. analis and H. potosi$n a$ in the Hawaiian stream insect community, and in the diet of native fishes, indicate that these species have become fundamental to energy flow within Hawaiian stream ecosystems. The aforementioned studies illustrate the apparent success of these two introduced Trichoptera species in Hawaiian streams; however, it should also be noted that these two species are found in streams throughout the world making the information in this study useful to tropical regions beyond the Hawaiian Islands.

The objective of this study was to evaluate the impact of a stream diversion on riffle Trichoptera communities by comparing species population biomass, density and individual larval body size above and below a diversion in a tropical stream. We hypothesized that reduced stream flow would be associated with reduced larval Trichoptera size, density and biomass. In this study we worked with two introduced Trichoptera, $C$. analis and $H$. potosina. It should be noted that in Hawaii, these organisms were previously identified to be $C$. pettiti (Banks) and H. arctia (Ross); however, these names have been recently reported to be incorrect and have been revised to $C$. analis and $H$. potosina (Flint et al. 2003).

\section{Description of study site}

All field data were collected above and below the first (most upstream) of three major diversions in Iao Stream. Iao Stream is a $13.4 \mathrm{~km}$ second order stream located in the Wailuku watershed on the northeastern side of the West Maui Mountains, on the island of Maui, Hawaii, draining an area of $\sim 16.3 \mathrm{~km}^{2}$. Iao Stream drains on the windward side of an extinct volcanic mountain ridge (Puu Kukui) with a peak elevation of $1756 \mathrm{~m}$. The headwaters originate at a slightly lower elevation that receives a mean annual rainfall of approximately $300 \mathrm{~cm}$ (Giambelluca et al. 1986, Shade 1997). Descending the elevational gradient from the 
headwaters to the mouth, the average annual rainfall decreases to $76 \mathrm{~cm}$ near the mouth (Giambelluca et al. 1986, Shade 1997). Due to the steep slopes, porous basalt geology and soil characteristics of the valley, Iao Stream can experience flash floods during relatively brief rain events (Shade 1997, Benbow et al. 1997, 2003). Thus, Iao Stream is characterized by having great variability in its daily, monthly, and yearly natural flow regime, making stream conditions highly unpredictable and flashy (Benbow 1999). These characteristics are common among Hawaiian streams (Resh \& Szalay 1995).

Iao Stream is the largest Maui stream to be heavily altered (Timbol \& Maciolek 1978). It has three large diversions that relocate stream water (over 18 MGD) into a system of three ditches (the Maniania Ditch, IaoWaikapu Ditch, and the Kama Ditch) that carry water downstream to surrounding agricultural fields such as sugar cane, pineapple, and macadamia nut (Shade 1997, Benbow 1999). In addition, the groundwater from this watershed is a crucial municipal water source on Maui (Shade 1997).

At base flow, the upstream reaches above the diversion can be characterized as having high flow, with numerous riffles and cascade habitats (Benbow et al. 1997, 2003). Downstream reaches below the diversion are characterized by lower flow, infrequent riffles and an increase of shallow pool habitats (McIntosh et al. 2002). In general, the substrate of Hawaiian streams can be characterized as a heterogeneous mixture of boulders, cobbles, and rocks (Kinzie et al. 1986), indicative of the patchy nature of Hawaiian stream habitats.

A USGS gauge station (16604500) is located approximately $0.5 \mathrm{~km}$ upstream of Kepaniwai Park, immediately above the first diversion and drains a basin of $15.5 \mathrm{~km}^{2}$ (USGS). The data from this gauge were used to determine discharge for this study and were compared to field measurements made according to Gordon et al. (1992).

\section{Materials and Methods}

\section{Field Collections}

Monthly benthic macroinvertebrate samples were collected above and below the first diversion of Iao Stream during the spring and summer of 2000 (27 April; 5 June; 8 July and 11 August). On each sampling date, the downstream location was sampled first in the morning and the upstream site was sampled a few hours later. Collections were made at sites $150 \mathrm{~m}$ upstream (N 20 52.829; W 156 32.750') and $\sim 50 \mathrm{~m}$ downstream (N 2 $2^{\circ} 52.993^{\prime} ; \mathrm{W} 156\left(32.324^{\prime}\right)$ of the first diversion. A grid of $100 \mathrm{~m}^{2}$, divided into $1 \mathrm{~m}^{2}$ cells, was established at each sampling location. Each grid area was chosen for a high estimated percentage $(80 \%)$ of riffle habitats; however, the downstream grid was longer and more narrow due a decrease in stream width and fewer riffle habitats. Both locations had less than $\sim 10 \%$ canopy cover. Dominant plant species were kukui (Aleurites moluccana Forst), guava (Psidium guajava L.) and various grasses.

On each sampling date, four cells were randomly selected from riffle habitats within each grid. A modified Surber sampler (area $625 \mathrm{~cm}^{2}$ ), constructed of PVC piping and a drift net, was used to collect macroinvertebrates. For each sample, the enclosed Surber sampler area was scraped vigorously by hand using a coarse plastic brush for $60 \mathrm{~s}$. The displaced benthic material drifted into the net (mesh size $125 \mu \mathrm{m}$ ), was collected in a $250 \mu \mathrm{m}$ sieve and preserved in $3-4 \%$ formalin for laboratory analysis. A total of eight samples, four from above and four from below the diversion, were collected on each sampling date.

In order to estimate the percent water withdrawal by the diversion, field discharge measurements were made upstream and downstream of the diversion on the last two sampling dates (8 July and 11 August) as described by Gordon et al. (1992). On all sampling dates, mean daily discharge data were obtained from the USGS gage upstream of the diversion. The percent water removal, due to the diversion, was calculated by taking the difference between the mean daily USGS gage data above the diversion and the field measured downstream discharge (July and August sampling dates). The percent water removed was then estimated for April and June using the corrected USGS mean daily discharge values.

Prior to each sample collection, surface water velocities were measured using the Ohio Professional electronic impeller flow meter (The Great Atlantic Trading Co. Ltd.). Median water column velocity was estimated using a correction $(\mathrm{k})$ of 0.85 for roughness of the bed (Newbury 1996). Depth was measured at four equidistant locations within the sampled area. Froude number was calculated in order to characterize the current flow relative to the critical velocity at the sampling point (Newbury 1996). A single water temperature reading was measured for each sample; however, total dissolved solids (TDS) were only measured from June to August and pH was measured only in June and July due to malfunctioning equipment. 


\section{Laboratory Analysis}

Each sample was examined for all macroinvertebrates and sorted into representative taxa. A sub-sampling procedure was utilized due to the large volume of benthic material. Each sub-sample was analyzed and subsequently corrected to the original sample size (Merritt \& Cummins 1996). Identifications were made to the lowest taxanomic level when possible using Merritt \& Cummins (1996). The genus and species identifications were sent to a known expert (Stephen R. Moulton) for confirmation. Mean densities (individuals $\cdot \mathrm{m}^{-2}$ ) were calculated for all identified macroinvertebrate taxa for each sampling date and for the total study period.

Head length (HL), post-orbital head length (PO) and abdomen width (AW) were measured in order to assess intra-instar size differences, facilitate instar separation and develop predictive regression models for each Trichoptera species. Headlength, PO and AW were measured using a dissecting microscope and ocular micrometer. A total of 745 individual Cheumatopsyche analis and 741 Hydroptila potosina were measured. Head length size frequency distributions were used to make visual separation of instars. Instar density and relative instar percent abundance were calculated for life cycle analyses.

Biomass was estimated for $2^{\text {nd }}$ to $5^{\text {th }} C$. analis instars and for a single group of $H$. potosina instars above and below the diversion. For $H$. potosina, we were unable to clearly separate the instars; thus, for biomass determination the $H$. potosina specimens were batched into a single group for all calculations and analyses. To expedite laboratory analyses, sub-samples of representative instars were used to measure biomass as ash-free dry mass (AFDM). For each instar, 2-30 individuals (depending on instar) were batched for dry mass and AFDM measurements. Each instar batch $(C$. analis, a total of 46 batches; $H$. potosina, a total of 6 batches) were weighed to the nearest $0.01 \mathrm{mg}$ and placed into a drying oven at $60^{\circ} \mathrm{C}$ for $12 \mathrm{~h}$ to measure dry mass $(\mathrm{mg})$ and then ashed at $500^{\circ} \mathrm{C}$ for $2 \mathrm{~h}$. Ash-free dry mass was determined by subtracting ash from dry mass. Individual AFDM (i.e., body size) was then calculated by dividing the total AFDM of each batch by the total number of larvae in that batch. Ash-free dry mass was measured at each site (upstream and downstream) except for the downstream $2^{\text {nd }}$ instars of $C$. analis due to an insufficient number of specimens. In addition, the $1^{\text {st }}$ instars of $C$. analis were too small for accurate AFDM measurements, even when pooled from both upstream and downstream locations.
To make the most accurate estimate of total species and instar biomass, a regression was calculated from individual larval measurements of AW and AFDM for each Trichopteran species (Benke 1997), and used to predict individual AFDM (i.e., body size) of the remaining individuals using the following models:

$$
\begin{aligned}
& \text { - C. analis : } \\
& \text { AFDM }=1.29 * \mathrm{AW} 2.91 \\
& \left(\mathrm{R}^{2}=0.75 ; \mathrm{N}=46\right) \\
& \text { - H. potosina : } \\
& \text { AFDM=0.17*AW } 1.88 \\
& \left(\mathrm{R}^{2}=0.83 ; \mathrm{N}=6\right)
\end{aligned}
$$

These models were constructed using pooled specimens from both upstream and downstream samples. There was no observed difference in the regression slopes between the upstream and downstream sites.

Standing stock biomass ( $\mathrm{mg}$ AFDM $\cdot \mathrm{m}^{-2}$ ) was calculated as the product of the mean sampling date individual body size (mg AFDM . individual ${ }^{-1}$ ) and mean sampling date density (individual $\cdot \mathrm{m}^{-2}$ ) (Benke 1997), and was determined for each of the measured instars of C. analis and $H$. potosina.

\section{Statistical Analyses}

Unless otherwise noted, all data were transformed $(\log 10+1)$ in order to increase normality, and independent t-tests were used to test for significance in mean total density, body size or biomass between the upstream and downstream sampling locations. Bivariate correlation, using the Spearman Rank Test, was performed to explore temperature and Froude number (arcsin transformed) in relation to total Trichopteran community biomass.

\section{Results}

\section{Discharge}

Field measurements of upstream discharge were 0.53 and $0.48 \mathrm{~m}^{3} \cdot \mathrm{s}^{-1}$ for July and August, respectively, while corresponding mean daily USGS upstream gauge data for July and August were $0.56 \mathrm{~m}^{3} \cdot \mathrm{s}^{-1}$ on both sampling dates. Downstream field measurements were 0.013 and $0.035 \mathrm{~m}^{3} \cdot \mathrm{s}^{-1}$ for July and August, respectively. Estimated downstream USGS discharge was calculated from a ratio of field and USGS measurements, due to the absence of a gage below the diversion. We estimated the USGS discharge to be 0.014 and $0.04 \mathrm{~m}^{3} \cdot \mathrm{s}^{-1}$ for July and August, respectively. The difference between upstream and downstream discharge ranged from approximately $92-97 \%$ resulting in 
only 3 - $8 \%$ downstream flow. However, these are estimates based upon wadable, base flow conditions, and undoubtedly do not reflect periods of elevated flow.

The mean $\mathrm{pH}$ was significantly greater upstream of the diversion (8.36) compared to downstream (7.95) $(\mathrm{t}=-2.75$, d.f. $=14, \mathrm{p}=0.016)$. No statistical difference was found between the temperature upstream $\left(19.7^{\circ} \mathrm{C}\right)$ and downstream $\left(20.3^{\circ} \mathrm{C}\right)$, and total dissolved solids upstream $\left(82.5 \mathrm{mg} \cdot \mathrm{L}^{-1}\right)$ and downstream $\left(83.3 \mathrm{mg} \cdot \mathrm{L}^{-1}\right)$. Froude number was significantly greater above the diversion (upstream $=0.266$; downstream $=0.126 ; \mathrm{t}=-4.53$, d.f. $=28, \mathrm{p}<0.01)$. Accordingly, the mean surface velocity was significantly greater above the diversion $\left(0.57 \mathrm{~m} \cdot \mathrm{s}^{-1}\right)$ compared to below $\left(0.14 \mathrm{~m} \cdot \mathrm{s}^{-1}\right)(\mathrm{t}=-6.56$, d.f. $=28, \mathrm{p}<0.01)$. It should be noted that two downstream velocity measurements were not taken due to malfunctioning equipment, thus all velocity and Froude statistics have a total of 30 measurements (i.e., d.f. $=28)$. Mean upstream depth $(0.32 \mathrm{~m})$ was significantly greater than below $(0.13 \mathrm{~m})$ the diversion $(\mathrm{t}=-4.42$, d.f. $=30, \mathrm{p}<0.01)$.

No correlation was found between temperature and mean total Trichoptera biomass (Spearman Rho = $0.301, \mathrm{~N}=32, \mathrm{p}=0.08$ ) or density (Spearman Rho = $0.337, \mathrm{~N}=32, \mathrm{p}=0.06$ ) over the entire sampling period. A significant positive correlation was found between Froude number and mean total Trichoptera biomass over the sampling period (Spearman Rho = $0.377, \mathrm{~N}=30, \mathrm{p}<0.04)$. Froude number was also significantly correlated with total density of each species; $C$. analis (Spearman $\mathrm{Rho}=0.393, \mathrm{~N}=30, \mathrm{p}=$ 0.032 ), and $H$. potosina (Spearman Rho $=0.719$, $\mathrm{N}=30, \mathrm{p}<0.01)$.

\section{Life cycle}

Life cycles were determined for each population upstream and downstream of the diversion over the four month period. Cheumatopsyche analis head length frequency distribution showed 5 instars in Iao Stream both above and below the diversion (Fig. 1). The head length range for each instar stage were the following: $1^{\text {st }}$ instar $0.0-0.2 \mathrm{~mm}, 2^{\text {nd }}$ instar $0.21-0.31$ $\mathrm{mm}, 3^{\text {rd }}$ instar $0.33-0.46 \mathrm{~mm}, 4^{\text {th }}$ instar $0.52-0.73 \mathrm{~mm}$, and $5^{\text {th }}$ instar $0.76-1.01 \mathrm{~mm}$. No distinct instar separation was possible for $H$. potosina. However, the Hydroptilidae family has been reported to have five larval stages, in which the first four are extremely small and the fifth resides in a specific purse-like case (Merritt \& Cummins 1996). In this study, many H. potosina were observed within a case, thus indicating the predominate presence of $5^{\text {th }}$ instars. Some specimens that were similar in size did not have a case, suggesting the pos- sible presence of $4^{\text {th }}$ instars. Undoubtedly, early instars were lost during sampling due to the $250 \mu \mathrm{m}$ sieve used. Thus, $H$. potosina was treated as one group probably representing the last two instars. Due to few, small $C$. analis instars we focused the analysis on the separated $4^{\text {th }}$ and $5^{\text {th }}$ instars to assess changes in standing stock biomass and larval body size.

Downstream of the diversion, relative instar density peaks were found within each $C$. analis instar group, implying a developing cohort, with peak $1^{\text {st }}$ instar abundance coinciding with $5^{\text {th }}$ instar decline in July (Fig. 1). Each instar was collected on each sampling date, upstream of the diversion but not downstream. Upstream of the diversion, peaks were also detected within each instar group over time and the populations were more uniform across all sampling dates compared to the downstream habitats (Fig. 1). Although no definitive instars were determined for $H$. potosina, last instars in cases were collected on all sampling dates above and below the diversion, indicating multiple cohorts over the 4 months. In addition, adult and pupae specimens of both species were found in the collected stream samples, but were not analyzed for this particular study. Thus, the coexistence of all determined larval instars for both $C$. analis and $H$. potosina suggested a multivoltine life cycle, where continuous reproduction is expected (Benke 1988). Although this study was only 4 months, multiple personal observations by all authors over 10 years indicate the presence of multiple generations of both species throughout the year supporting a multivoltine life cycle.

\section{Density, individual body size and biomass}

The mean total density of $C$. analis was 799 and 425 individual $\cdot \mathrm{m}^{-2}$, upstream and downstream, respectively. Hydroptila potosina had greater densities at both locations, with 1419 individual $\cdot \mathrm{m}^{-2}$ upstream and 854 individual $\cdot \mathrm{m}^{-2}$ downstream of the diversion. Both species had significantly higher densities upstream of the diversion $(C$. analis: $\mathrm{t}=-3.10, \mathrm{df}=30, \mathrm{p}=0.004$; $H$. potosina: $\mathrm{t}=-2.61, \mathrm{df}=30, \mathrm{p}=0.014$; Fig. 2 ).

Site had no significant effect on mean individual body size of either $4^{\text {th }}$ (downstream $=0.22 \mathrm{mg}$. individual ${ }^{-1}$, upstream $=0.19 \mathrm{mg} \cdot$ individual $^{-1} ; \mathrm{t}=0.84, \mathrm{df}=40.84$, $\mathrm{p}=0.404)$ or $5^{\text {th }}$ (downstream and upstream $=0.73 \mathrm{mg}$. individual $\left.^{-1} ; \mathrm{t}=-0.23, \mathrm{df}=147.64, \mathrm{p}=0.819\right)$ C. analis instars (Fig. 3). However, the mean body size of $H$. potosina larvae was significantly greater upstream $\left(0.04 \mathrm{mg} \cdot\right.$ individual $\left.^{-1}\right)$ than compared to downstream $\left(0.03 \mathrm{mg} \cdot\right.$ individual $\left.^{-1}\right)(\mathrm{t}=-3.21, \mathrm{df}=584, \mathrm{p}=0.001$; Fig. 3). 


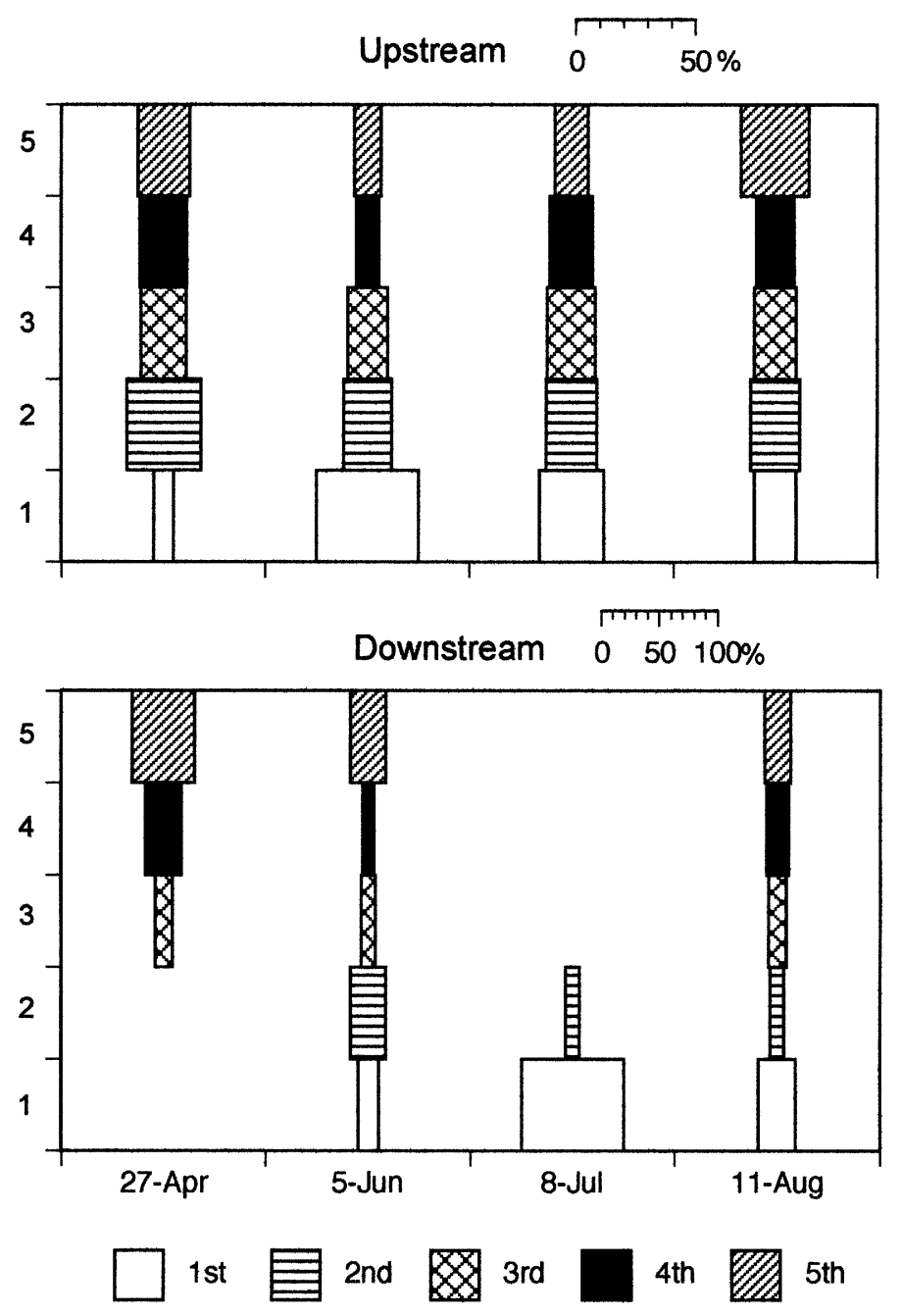

Fig.1. Relative percent abundance for instar stages (1-5) of Cheumatopsyche analis upstream and downstream of a diversion in Iao Stream, Maui, Hawaii, from April to August 2000.

Over the entire sampling period, $C$. analis mean total biomass (all instars) was greater than $H$. potosina at both sites. Mean total biomass was significantly lower downstream of the diversion, with a $38 \%$ and $54 \%$ reduction for $C$. analis (upstream $=125.5 \mathrm{mg} \cdot \mathrm{m}^{-2}$; downstream $=76.8 \mathrm{mg} \cdot \mathrm{m}^{-2} ; \mathrm{t}=-3.61$, df $=16.91$, $\mathrm{p}=0.002)$ and $H$. potosina (upstream $=51.6 \mathrm{mg} \cdot \mathrm{m}^{-2}$, downstream $=23.6 \mathrm{mg} \cdot \mathrm{m}^{-2} ; \mathrm{t}=-2.75, \mathrm{df}=19.94, \mathrm{p}=$ 0.012), respectively. Mean total Trichoptera community standing stock biomass was also significantly greater above the diversion over the entire sampling period $\left(178.3 \mathrm{mg} \cdot \mathrm{m}^{-2}\right.$ and $112.86 \mathrm{mg} \cdot \mathrm{m}^{-2}$ for upstream and downstream, respectively; $\mathrm{t}=-3.10, \mathrm{df}=16.28, \mathrm{p}=$ 0.007; Fig. 4).

\section{Discussion}

Many tropical island streams have been altered with diversions to remove most, or all, stream flow. Measurements from this study indicated that from April to August 2000, a 92 - $97 \%$ reduction in stream flow was found below the first diversion in Iao Stream, Maui, Hawaii. In addition, visual observations noted a de- 


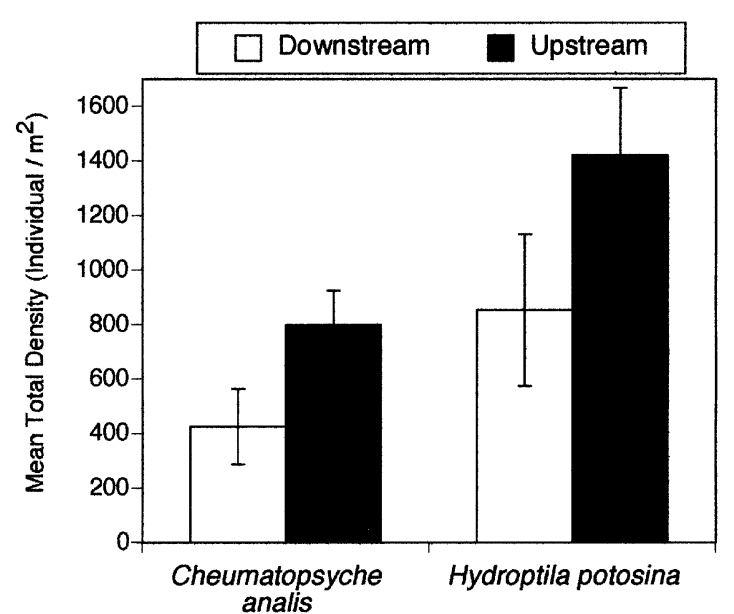

Fig. 2. Mean total density (individuals $\cdot \mathrm{m}^{-2}$ ), with standard error bars illustrated, of Cheumatopsyche analis and Hydroptila potosina in Iao Stream over the entire sampling period from April to August. Both species had a greater number of individuals upstream of the diversion (C. analis: $\mathrm{p}<0.01$ and $H$. potosina: $\mathrm{p}=0.014)$

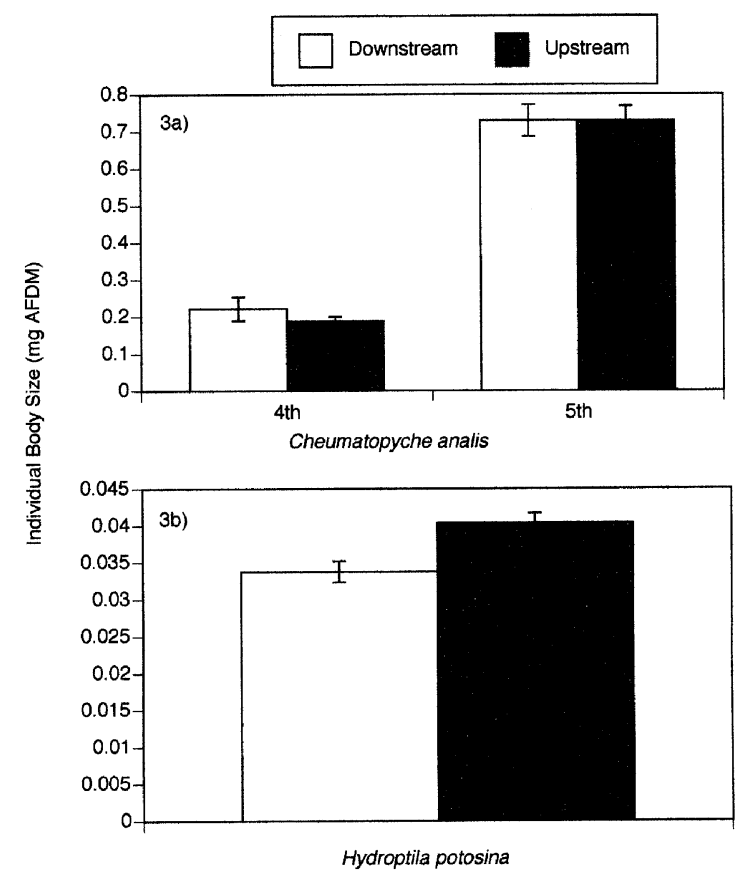

Fig. 3. Mean individual body size [mg Ash-free dry mass (AFDM)], with standard error bars illustrated, for $4^{\text {th }}$ and $5^{\text {th }}$ instars of $\mathrm{Cheu}$ matopsyche analis (Fig. 3a) and Hydroptila potosina (Fig. 3b) from sites upstream and downstream of a diversion in Iao Stream, Maui, Hawaii. Significant difference was observed for Hydroptila potosina between sites $(\mathrm{p}<0.01)$.

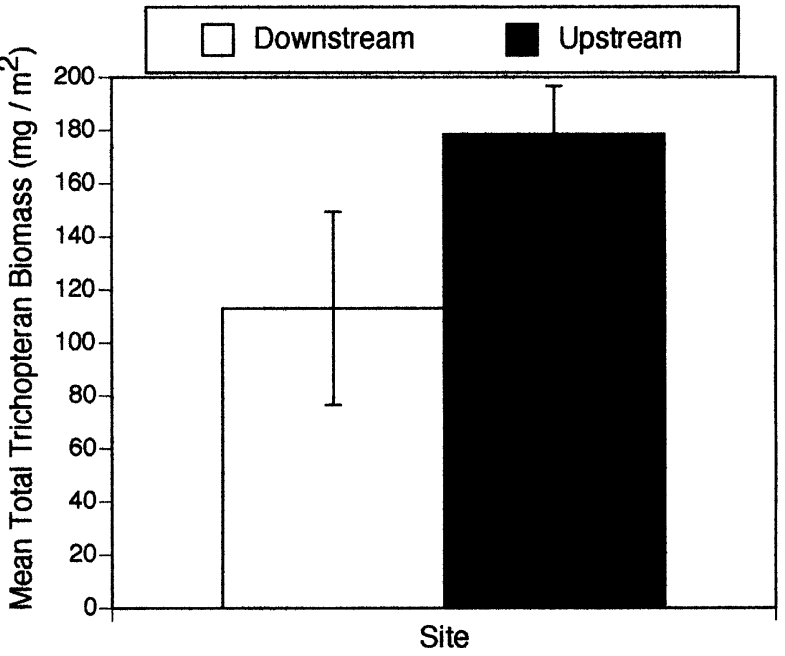

Fig. 4. Mean total Trichopteran biomass $\left(\mathrm{mg} \cdot \mathrm{m}^{-2}\right)$, with standard error bars illustrated, upstream and downstream of an Iao Stream diversion in Maui, Hawaii, during the summer of 2000. Significant difference between habitats in total biomass was observed $(\mathrm{p}<0.01)$.

crease in overall stream depth, width, and fast-flowing riffle habitats below the diversion. These results provide evidence that an overall reduction of suitable and colonizable benthic habitat was found below the first diversion in Iao Stream; however, few studies have quantitatively addressed how this type of disturbance may alter the benthic biotic communities of tropical island streams.

The most recent studies that have addressed reduced stream flow, due to diversion, and the subsequent effect on macroinvertebrate populations in Hawaii were by McIntosh (2002), Wolff (2001), and Kido (1996). McIntosh et al. (2002) found the absence of three macroinvertebrate groups below the same diversion in Iao Stream and an overall reduction in the densities of all riffle macroinvertebrates. The correlation between stream flow (Froude number) and Trichoptera biomass found in the present study also supports the hypothesis that reduced stream flow negatively affects the extent and characteristics of downstream flow habitat for aquatic insects in Hawaiian streams. Further, Kido (1996) found a significant decrease in algae and invertebrate densities below a new diversion on the island of Kauai.

The life cycles of both Trichoptera play an important role in determining community biomass and secondary production in Iao Stream. Cheumatopsyche analis 
seemed to have a multivoltine life cycle, with five instar stages both above and usually below the diversion. In addition, upstream of the diversion similar proportions of each instar group were present on each date; whereas, downstream, a single instar group sometimes accounted for more than $70 \%$ of the population (Fig. $1)$. This could suggest that fewer generations of $C$. analis are found downstream of the diversion, resulting in lower standing stock biomass available for higher trophic levels.

We only collected one or two instars of $H$. potosina. Other studies have documented five instars for the genus Hydroptila (Wiggins 1996), and thus we are assuming that the earlier instars were too small to be sampled accurately in this study; however, this was consistent above and below the diversion. Other researchers have also addressed difficulty in early instar identification, sampling error and voltinism in the determination of Trichoptera species (Waters 1979, Marchant 1986). This suggests that the density, and thus standing stock biomass, estimates for $H$. potosina were probably underestimated in this study.

The presence of both Trichoptera species on all sampling dates, in addition to several year-long field observations seem to suggest that $C$. analis and $H$. potosina have a multivoltine life cycle, both above and below the diversion; however, additional year long investigations are needed for confirmation. Kondratieff et al. (1997) found $C$. analis to have a multivoltine life cycle in a Molokai, Hawaii stream. The significance of a multivoltine life cycle is that a constant level of biomass is available to higher trophic levels throughout the year, and thus, is important to energy flow in the stream (Sanchez \& Hendricks 1997). The multivoltine life cycle in conjunction with the large Trichoptera densities found in Hawaiian streams, (ranging from $23 \%$ to $77 \%$ of the riffle macroinvertebrate community; McIntosh et al. 2002) reveals the important role of these species in the Hawaiian benthic community. In addition, the possibility of more Trichoptera generations above the diversion suggest that a greater amount of biomass and energy is available upstream. However, in order to completely understand the growing role of these two introduced species in Hawaiian streams, the need exists for a more detailed investigation into the life history, secondary production, behavior, and community interactions of these common Trichopteran species, especially $H$. potosina (Kido 1996).

In this study, the total Trichoptera biomass was significantly greater in the upstream habitats compared to below the diversion, suggesting that the overall habitat and food availability is probably greater for these two species above the diversion. Sheldon \& Walker (1997) determined that reduced flow and flood frequency shifted the epilithic food resource of grazing prosobranchs (e.g., aquatic snails) from microbial (high nutritional value) to algal (low nutritional value) dominance. They speculate that this food resource shift has reduced populations of these species due to the high bioenergetic cost of low quality food availability (Sheldon \& Walker 1997). Furthermore, Benbow (1999) addressed biomass and secondary production of Telmatogetan torrenticola, an endemic Hawaiian chironomid, between two summers of significantly different discharge in Iao Stream. In Benbow's study, he speculated that reduced stream flow, due to drought, lowered the availability of food resources for T. torrenticola (Benbow 1999). Similar reductions in food availability in Iao Stream, similar to those observed by Benbow (1999) might account for the significant Trichoptera biomass reduction found in this study. Our data show that reduced flow volume has a negative effect on total biomass of $C$. analis and $H$. potosina.

Although total biomass decreased for both Trichoptera species below the diversion, a closer analysis of the two components of biomass (density and body size) can lead to a better understanding of factors affecting these two species downstream of the diversion. Both species had a reduction in density below the diversion (Fig. 2); however, individual body size varied between the two species. Individual mean body size (as AFDM) for $C$. analis showed no significant change between habitats in individual $4^{\text {th }}$ and $5^{\text {th }}$ instars (Fig. $3 a)$. Thus, the significant reduction of standing stock biomass is attributed to the lowered density below the diversion. Conversely, the body size of $H$. potosina instars was significantly smaller downstream of the diversion (Fig. 3b). Abdomen size in $5^{\text {th }}$ instars of the family Hydroptilidae have been reported to grow disproportionately large due to utilization as a food reservoir (Wiggins 1996). Because we used abdomen width to predict AFDM, changes in AFDM reflect changes in abdomen width variation. Thus, the larger body size in $H$. potosina upstream of the diversion could be indicative of greater food availability and/or acquisition. Benbow (1999) determined that individual growth rates of $T$. torrenticola $4^{\text {th }}$ instars had faster growth rates in optimal fast flowing habitats compared to lower flowing or sub-optimal habitats. He speculated that body size reduction was limited by habitat characteristics, which regulate food quality and quantity (Benbow 1999). Similarly, the reduction in H. potosina body size observed in this study suggests that water removal alters habitat characteristics that may have a 
cascading affect on food quality, availability, and acquisition. However, other factors could have influenced body size of $H$. potosina in the downstream riffle habitats. Variables such as fluctuating temperatures, $\mathrm{pH}$, and biotic interactions (e.g., competition and predation) may have affected the growth and development of $H$. potosina. These variations were not addressed in detail in this study, but all can potentially be affected by flow volume (Benke et al. 1988, Benke 1996).

Negative cascading effects due to diversions could be impacting higher trophic levels, especially native Hawaiian fish. According to two native Hawaiian fish food web models developed by Kido (1997a), the two introduced Trichoptera are one of three main food sources for native fish. The other two main fish food sources are Diptera and algae; however, similar consequences (e.g., lowered densities, AFDM and biomass) found within the Trichoptera due to flow reduction could also negatively affect Diptera and algal populations. McIntosh et al. (2002) found $\sim 50 \%$ reduction in Diptera populations below the diversion. Visual observations of the sparse fish populations below the diversion also support this theory (Benbow, personal observation). More complex trophic interactions could also be affected by water removal. Two major food resources for $C$. analis and $H$. potosina are detritus and algae (Kido 1997a). Reduced algal populations, due to habitat loss, and reduced detritus, due to lack of transport by reduced stream flows, could lower the number and size of $C$. analis and $H$. potosina below the diversion, thus reducing the amount of energy available for native fish.

\section{Conclusions}

The main objective of this study was to determine the effect of water removal on two introduced Trichoptera, $C$. analis and $H$. potosina, above and below the first diversion in Iao Stream, Maui, Hawaii. This study documents the densities, larval body size and standing stock biomass of two introduced caddisflies that are found worldwide. This study concluded that the diversion had substantial negative affects on the standing stock biomass of both Trichoptera. Both species had greater densities above the diversion; however, individual body size (as AFDM) of $H$. potosina instars, but not $C$. analis instars, was significantly lower below the diversion. Our results suggest that reduced habitat due to lowered stream flow limits the densities of both species below the diversion, whereas lowered food quantity and quality may differentially affect $H$. potosina biomass through smaller body sizes. Furthermore, the data from this study suggest that $C$. analis and $H$. potosina have multivoltine life cycles, and thus provide sustained levels of biomass to higher trophic levels throughout the year. In order to understand the effects of water removal in tropical streams, more research is needed on the structure and function of the aquatic community and trophic interactions within natural and diverted streams. The need also exits for more research into the energetics of Hawaiian streams, specifically biomass and secondary production analyses of the entire macroinvertebrate community.

\begin{abstract}
Acknowledgements
We would like to thank Leslie Orzetti, Brian Condon, Tim Fernandez, Kathy Jennings, Kathy Kopec, Sara Sauter and the Earthwatch Institute volunteers for their valuable field assistance, Chris Craft and Bill Jones for their support of the first author, Stephen R. Moulton for his confirmations of genus and species identification, and the Hawaiian Division of Aquatic Resources, Department of Land and Natural Resources, Honolulu, Hawaii. This research was supported by Earthwatch Institute and the Center for Field Studies and the Department of Biology of the University of Dayton, Dayton, Ohio.
\end{abstract}

\section{References}

Benbow M.E., Burky A.J. \& Way C.M. 1997. — Larval habitat preference of the endemic Hawaiian midge, Telmatogeton torrenticola Terry (Telmatogetoninae). Hydrobiologia, 346, 129-136.

Benbow M.E., Burky A.J. \& Way C.M. 1999. - Natural spate disturbance and decreased discharge in a Hawaiian stream: fluctuating stability in a torrential environment. Dissertation. University of Dayton, Dayton, Ohio, 394 p.

Benbow M.E., Burky A.J. \& Way C.M. 2003. — Life cycle of a torrenticolous Hawaiian chironomid (Telmatogeton torrenticola): stream flow and microhabitat effects. Ann. Limnol. - Int. J. Lim., 39, 103-114.

Benstead J.P., March J.G., Pringle C.M. \& Scatena F.N. 1999. — Effects of a low-head dam and water abstraction on migratory tropical stream biota. Ecol. App., 9, 656-668.

Benke A.C., Hall C.A.S, Hawkins C.P., Lowe-McConnell R.H., Stanford J.A., Suberkropp K. \& Ward J.V. 1988. — Bioenergetic considerations in the analysis of stream ecosystems. J. N. Am. Benthol. Soc., 7, 480-502.

Benke A.C. 1996. - Secondary production of macroinvertebrates. Pages 557-578 in Methods in Stream Ecology. Hauer F.R. \& Lamberti G.A. (Eds.). Academic Press, New York, NY.

Benke A.C. \& Wallace J.B. 1997. - Trophic basis of production among riverine caddisflies: implications for food web analysis. Ecology, 78, 1132-1145.

Brasher A.M. 1996. - Monitoring the distribution and abundance of native gobies ('o'opu) in Waikolu and Pelekunin Streams on the Island of Molokai'i. Cooperative National Park Resources Studies Unit, University of Hawai'i at Manoa. Technical Report 113.

Brasher A.M. 1997a. — Life history characteristics of the native Hawaiian stream snail Neritina granosa (hihiwai). Cooperative $\mathrm{Na}-$ tional Park Resources Studies Unit, University of Hawai'i at Manoa. Technical Report 114.

Brasher A.M. 1997b. - Habitat use by fish ('o'opu), snails (hihiwai), shrimp ('opae) and prawns in two streams on the Island of Molokai'i. Cooperative National Park Resources Studies Unit, University of Hawai'i at Manoa. Technical Report 116. 
Englund R.A. \& Polhemus D.A. 2001. — Evaluating the effects of introduced rainbow trout (Oncorhynchus mykiss) on native stream insects on Kauai Island, Hawaii. J. Insect Conserv., 5, 265-281.

Flint O.S. \& Englund R.A. 2003. - A Reassessment of New State Records of Trichoptera occurring in Hawai'i with discussion on origins and potential ecological impacts. Bishop Mus. Occ. Pap., $73,31-40$.

Giambelluca T.W., Nullet M.A. \& Schroeder T.A. 1986. — Rainfall atlas of Hawaii. State of Hawaii, Department of Land and Natural Resources, Division of Water and Land Development, Report R76.

Gordon N.D., McMahnon T.A \& Finlayson B.L. 1992. - Stream Hydrology: an Introduction for Ecologists. Wiley \& Sons, Chichester, England. 526 p.

Hawaii Cooperative Park Service Unit. 1990. - Hawaii stream assessment: A preliminary appraisal of Hawaii's stream resources. The National Park Service. Report 84.

Kido M.H. 1993. - Insect introductions and diet changes in an endemic Hawaiian amphidromous goby, Awaous stamineus (Pisces: Gobiidae). Pac. Sci., 47, 43-50.

Kido M.H. 1996. - Recovery processes in Hawaiian streams. Pages 76-92 in Will stream restoration benefit freshwater, estuarine, and marine fisheries? Proceedings of the Hawaii Stream Restoration Symposium, Devick W.S. (Ed).

Kido M.H. 1997a. — Food webs and feeding dynamics of coexisting native Hawaiian stream gobies. Micronesica, 30, 71-82.

Kido M.H. 1997b. — Food relations between coexisting native Hawaiian stream fishes. Envir. Biol. Fishes, 49, 481-494.

Kinzie III R.A., Ford J.I., Yuen A.R. \& Chow S.J.L. 1986. - Habitat modeling of Hawaiian streams. Water Resources Research Center University of Hawaii at Manoa. Report 171, 126 p.

Kondratieff B.C., Bishop R.J. \& Brasher A.M. 1997. — The life cycle of an introduced caddisfly, Cheumatopsyche analis (Banks) (Trichoptera: Hydropsychidae) in Waikolu Stream, Molokai, Hawaii. Hydrobiologia, 350, 81-85.

March J.G., Pringle C.M., Townsend M.J. \& Wilson A.I. 2002. Effects of freshwater shrimp assemblages on benthic communities along an altitudinal gradient of a tropical island stream. Freshwat. Biol., 47, 377-390.

Marchant R. 1986. - Estimates of annual production for some aquatic insects from the La Trobe River, Victoria. Aust. J. Mar. Freshw. Research, 37, 113-120.

McIntosh M.D., Benbow M.E. \& Burky A.J. 2002. — Effects of stream diversion on riffle macroinvertebrate communities in a Maui, Hawaii, stream. River Res. Appl., 18, 569-581.

Merritt R.W. \& Cummins K.W. 1996. - An Introduction to the Aquatic Insects of North America. Second edition. Kendall /Hunt, Dubuque, Iowa.

Newbury R.W. 1996. — Dynamics of Flow. Pages 75-92 in Methods in Stream Ecology. Hauer F.R. \& Lamberti G.A. (Eds.). Academic Press, San Diego, California.
Poff N.L., Allen J.D., Bain M.B., Karr J.R., Prestegaard K.L., Richter B.D., Sparks R.E. \& Stromberg J.C. 1997. — The natural flow regime: a paradigm for river conservation and restoration. Bioscience, 47, 769-784.

Pringle C.M., Freeman M.C. \& Freeman B.J. 2000. — Regional effects of hydrologic alterations on riverine macrobiota in the New World: Tropical-Temperate comparisons. Bioscience, 50, 807-823.

Resh V.H. \& Szalay F.A.D. 1995. - Streams and rivers of oceania. Pages 717-736 in River and Stream Ecosystems. Cushing C.E. Cummings K.W. \& Minshall, G.W. (Eds.). Elsevier, Amsterdam.

Sanchez M. \& Hendricks A.C. 1997. — Life history and secondary production of Cheumatopsyche spp. in a small Appalachian stream with two different land uses on its watershed. Hydrobiologia, 354, 127-139.

Shade P.J. 1997. — Water Budget for the Iao Area, Island of Maui, Hawaii. United States Geological Survey, Water-Resources Investigations, Report 97-4244.

Sheldon F. \& Walker K.F. 1997. — Changes in biofilms induced by flow regulation could explain extinctions of aquatic snails in the lower River Murray, Australia. Hydrobiologia, 347, 97-108.

Timbol A. \& Maciolek J.A. 1978. - Stream channel modification in Hawaii. Part A: statewide inventory of streams; habitat factors and associated biota. National Stream Modification Team, U.S. Fish and Wild. Ser., Columbia, MO, Report FWS/OBS-78/16.

Way C.M. \& Burky A.J. 1991. — A preliminary survey of macroinvertebrates and a preliminary assessment of the diet of the endemic Hawaiian goby ('O'opu Alamo'o), Lentipes concolor (Gill). In: New directions in research, management and conservation of Hawaiian stream ecosystems. Proc. 1990 Symp. Freshwat. Stream Biol. Fish. Mgmt. State Hawaii, Dept. Land Nat. Res., Div. Aquat. Res., Honolulu, Hawaii.

Way C.M., Burky A.J., Harding J.M., Hau S. \& Puleloa W.K.L.C. 1998. - The reproductive biology of the endemic goby Lentipes concolor, from Makamaka'ole Stream, Maui, and Waikolu Stream, Moloka'i. Envir. Biol. Fishes, 51, 53-65.

Waters T.F. 1979. - Influence of benthos life history upon the estimation of secondary production. J. Fish. Res. Board Can., 36, 1425-1430.

Wiggins G.B. 1996. — Trichoptera. Pages 309-349 in An introduction to the aquatic insects of North America, Second edition. Merritt, R.W. \& K.W Cummins (Eds.). Kendall /Hunt, Dubuque, Iowa.

Wolff R.H. 2000. — Seasonal recovery patterns of Hawaiian stream flora and fauna, Wainiha River, Kauai, Hawaii. Master's Thesis. Department of Zoology, University of Hawaii at Manoa.

Zimmerman E.C. 2001. - Insects of Hawai'i. Volume 1: Introduction with a new preface and dedication. Originally published in 1947. University of Hawaii Press. Honolulu, Hawaii. 